\title{
Osteomyelitis: A manifestation of sickle cell anemia
}

\author{
Salma M. AlDallal* \\ Haematology Laboratory Specialist, Haematology Department, Amiri Hospital, Kuwait
}

\begin{abstract}
Osteomyelitis is an infectious stage of bones associated with distinct clinical microbiology. In sickle cell anemia, an early detection and diagnostic accuracy of osteomyelitis would establish an immediate treatment module for preventing bone destruction and deformity. This mini-review highlights the different diagnostic tools and courses of treatment involved in the accurate diagnosis of osteomyelitis.

In approximately $50 \%$ of acute osteomyelitis cases, blood culture is considered as an essential tool for correct diagnosis of the infection [1]. The gold standard tools for the diagnosis include bone biopsy test with histopathological examination and tissue culture, (both aerobic and anaerobic bacteria culture). Another study showed the implementation of radioisotope imaging for detecting acute osteomyelitis. Among all the detection tools discussed MRI is considered as an efficient tool for the diagnosis of osteomyelitis in SCA patients.
\end{abstract}

This mini-review aims at creating awareness about the wide range of symptoms and appearances for accurate diagnosis and appropriate treatment modules.

\section{Background}

Sickle cell anemia (SCA) is an autosomal recessive genetic disorder characterized by the synthesis of defective hemoglobin $(\mathrm{Hb})$ known as sickle hemoglobin (HbS). HbS formation results from single amino acid substitution at position 6 , where glutamic acid gets replaced by valine, in the $\beta$ globin gene. Abnormalities in both the $\beta$ globin genes, either heterozygous (i.e., combined with other abnormal hemoglobins such as hemoglobin $\mathrm{C}$ [HbSC] or $\beta$ thalassemia [HbS-thal]) or homozygous (HbSS), leads to the development of the disease. However, an individual may exhibit sickle cell trait without resulting in anemia, if he/she has a combination of both abnormal ( $\mathrm{HbS}$, mild form of disease) and normal gene (HbA) (Ejindu, et al., 2007). SCA affects millions worldwide; especially, it is widespread among the people with ancestral origin from sub-Saharan Africa, Saudi Arabia, Spanish-speaking regions, India and Mediterranean countries [2].

Under low oxygen concentration, red blood cells (RBCs) that contain an abnormal form of $\mathrm{Hb}$ become deformed (or sickle-shaped) and rigid. This impedes their ability to pass through microcirculation, with frequent clotting and thrombosis. The consequence of the obstruction is the production of ischemia and infarction. Infarcts are the outcome of infarction, which are small localized areas of dead tissues. These can affect several organs of the infected person, including brain, lungs, bones and spleen, and are also responsible for most clinical manifestations. Tissue infarctions, generally referred to as vaso-occlusive crisis (VOC), are present as pain or swelling. VOC is the most common and earliest forms of clinical manifestation, which is frequently observed in the pediatric population [3-6]. Previous researches showed higher susceptibility of SCA children towards a rare form of osteomyelitis, i.e., Salmonella osteomyelitis. Immunodeficiency caused by splenic dysfunction, tissue infarction, and excess iron content leads to increased risk of osteomyelitis [7-9].

VOC and osteomyelitis are roughly identical in the acute stage, and both are associated with a rise in C-reactive protein (CRP) level and erythrocyte sedimentation rate (ESR). For this reason, establishing the correct diagnosis is essential so as to assist in the formulation of an effective treatment plan. Diagnosis of osteomyelitis is achieved through physical examinations and standard laboratory tests like positive blood culture or joint aspirate, but negative blood culture does not exclude the diagnosis of the disease [9-11]. In addition, magnetic resonance imaging (MRI) is also considered as an effective tool in the diagnosis of osteomyelitis [11,12]; however, they are not always readily accessible due to cost or unavailability. Ultrasound (US) scans have been used in the diagnosis of osteomyelitis in SCA patients, showing sensitivity of $74 \%$ and specificity of $63 \%$ [12-14]. The aim of this mini-review is to summarize the different diagnostic tools for the detection of osteomyelitis in SCA patients that would assist in its treatment.

\section{Osteomyelitis in SCA}

Bone infection is a serious complication in SCA and a major cause of hospitalization. Previous researchers have reported that SCA patients become very susceptible to unusual organisms in which a preponderance of salmonella-caused osteomyelitis has been observed [15-17].

Bahebeck, et al. [18] reported that the relative rate of complications in osteomyelitis was almost $13 \%$. There is a decrease in the quality of life due to the morbidity of chronic osteomyelitis in association with varied effects of hemoglobinopathy. In addition, there are many factors that lead to a high frequency of infection in these patients. Hyposplenism is an important factor that follows infarction, which mainly occurs during childhood, and subsequent fibrosis [19]. Medullary bone infarction and

Correspondence to: Dr. Salma M. AlDallal, Haematology Laboratory Specialist, Haematology Department, Amiri Hospital, Kuwait, Tel: +965-90981981; Fax: +965-22463790; E-mail: dr.s.aldallal@outlook.com

Key words: bacterial culture, $\beta$ thalassemia, infarction, infection, osteomyelitis, sickle cell anemia

Received: April 06, 2017; Accepted: April 22, 2017; Published: April 24, 2017 
necrosis creates an apt condition for bacterial growth and spreading. Furthermore, frequent hospital stays might lead to increased exposure of the patients to certain pathogenic bacteria strains [20].

Osteomyelitis is commonly seen infection affecting the tibia, diaphysis of femur and humerus, along with the infection of the vertebras. The infection is hematogenous in nature due to its delayed onset. The most common casual organism is Salmonella (especially Salmonella enteritidis, Salmonella typhimurium, Salmonella paratyphi $B$, Salmonella choleraesuis and Salmonella aureus) followed by Staphylococcus aureus, which is seen in $10 \%$ of patients suffering from sickle cell-related osteomyelitis. Certain other causative bacterial species are Enterobacter spp., Haemophilus influenza, and Escherichia coli $[1,21,22]$ (Table 1). Bacteremia caused due to the gram-negative microbes is believed to result from sickling within the mesenteric vessels and subsequent gastrointestinal infarction [23]. Moreover, the leg ulcers often lead to the direct spread of the infection [7].

\section{Diagnosis of osteomyelitis}

In SCA, osteomyelitis diagnosis can be a major problem for health providers, where unsuccessful identification of the disease may end up with severe bone damage and life-threatening infection. As mentioned earlier, osteomyelitis affects mainly the long bones, but other bones may also be affected. Patients with osteomyelitis may suffer from pain, swelling, fever and increased flow of inflammatory markers in the blood serum. This shows parallel characteristics with that of painful bone crises, which makes differentiation of bone infarction a difficult task [7].

Laboratory tests for the detection of osteomyelitis are usually nonspecific; CRP and ESR are often elevated. However, in the nonavailability of microbiological and radiological data, both the tests lack specificity. The CRP test is more reliable than ESR for response assessment in the case of young children [24].

In approximately $50 \%$ of acute osteomyelitis cases, blood culture is considered as an essential tool for correct diagnosis of the infection [7]. The gold standard tools for the diagnosis include bone biopsy test with histopathological examination and tissue culture, (both aerobic and anaerobic bacteria culture). Furthermore, mycobacterial and fungal cultures should also be performed in case of any clinical doubts regarding the existence of the causative organisms [25]. However, if the infection is not suspected, then blood cultures are not helpful. In such cases, blood sampling is done at later stages of the treatment course.

Radiographic findings of osteopenia, sclerosis, and periosteal inflammation are seen in both stages of infection and infarction.

Table 1. Source of organisms cultured from 32 patients.

\begin{tabular}{|l|l|l|l|l|l|}
\hline Organism & Source & & & Total & $\begin{array}{l}\text { Percentage } \\
\text { of Total }\end{array}$ \\
\hline & Blood Culture & Pus Culture & Blood & + Pus Culture & \\
\hline Salmonella & 4 & 11 & 3 & 18 & $50-0$ \\
\hline $\begin{array}{l}\text { Staphylococcus } \\
\text { aureus }\end{array}$ & 2 & 4 & & 6 & $16-7$ \\
\hline $\begin{array}{l}\text { Escherichia coli } \\
\text { Pseudomonas }\end{array}$ & & 3 & & 3 & $8-3$ \\
\hline Klebsiella & 1 & 3 & & 3 & $8-3$ \\
\hline Proteus & & & 1 & 2 & $5-6$ \\
\hline $\begin{array}{l}\text { Anaerobic } \\
\text { streptococcus }\end{array}$ & & 2 & & 2 & $5-6$ \\
\hline Citrobacter & 1 & 1 & & 1 & $2-8$ \\
\hline Total & 8 & & & 1 & $2-8$ \\
\hline
\end{tabular}

Therefore, the radiographic features are nonspecific and primarily normal [26]. Other infection detection tools like ultrasonography (US) are also used for its advantageous features like portability, quickness, non-invasiveness, and better acceptability by the children [27]. The US shows the extraosseous pathology in acute cases and may also show periosteal elevation [28]. The US test exhibits $74 \%$ sensitivity in diagnosis osteomyelitis in SCA [28-31]. However, the main diagnostic finding, i.e., the presence of subperiosteal fluid, is non-specific and can also be present during VOC [28].

Another study showed the implementation of radioisotope imaging for detecting acute osteomyelitis. A combination of ${ }^{99 \mathrm{~m}} \mathrm{Tc}$ sulphur colloid and ${ }^{99 \mathrm{~m}} \mathrm{Tc}$-diphosphonate $[32,33]$ or ${ }^{99 \mathrm{~m}} \mathrm{Tc}$ with gallium seems to improve the test accuracy [34]. However, the test still resulted in false positives and false negatives due to which the health providers discontinued its use. Even radio-labeled leucocyte scans failed to differentiate between osteomyelitis and infarction [35].

Among all the detection tools discussed above MRI is considered as an efficient tool for the diagnosis of osteomyelitis in SCA patients. This is because MRI efficiently shows the pathological alterations even before they are detected on normal radiographs [26]. The accuracy of MRI can also be increased using gadolinium enhancement $[13,36]$; however, this does not guarantee $100 \%$ accuracy in distinguishing osteomyelitis from infarction [26,37]. For overcoming this limitation, MRI can be performed after obtaining the culture results for precise localization of the lesion and monitoring of the response of patients to various medications [38].

\section{Treatment of osteomyelitis}

The microorganism detected in the blood usually determines the antibiotic choice. In the case of suspected or confirmed osteomyelitis, a third line cephalosporin, i.e., ceftriaxone, is used for treating Salmonella infections. Ciprofloxacin is considered as a suitable alternative for treating Salmonella infection in older children. In the case of adults, who have been infected with other species, such as Staphylococcus empirical antibiotic treatment should be followed [30]. In confirmed cases of osteomyelitis, a six-week treatment plan needs to be followed. If the radiographic imaging reveals fluid accumulation at the infection site, immediate drainage is recommended [30].

\section{Conclusion}

This mini-review presents one of the major manifestations of SCA, i.e., osteomyelitis. It aims at creating awareness about the wide range of symptoms and appearances for accurate diagnosis of the disease and plan for appropriate treatment modules.

\section{Acknowledgment}

The author is thankful to www.manuscriptedit.com for providing English language editing and proofreading services for this manuscript.

\section{Competing interest}

The author declares that she has no competing interests.

\section{References}

1. Ejindu VC, Hine AL, Mashayekhi M, Shorvon PJ, Misra RR (2007) Musculoskeletal manifestations of sickle cell disease. Radiographics 27: 1005-1021. [Crossref]

2. Serjeant GR (2013) The natural history of sickle cell disease. Cold Spring Harb Perspect Med 3: a011783. [Crossref]

3. Rees DC, Williams TN, Gladwin MT (2010) Sickle-cell disease. Lancet 376: 2018 2031. [Crossref] 
4. Mayo Clinic (2016) Diseases and Conditions- Sickle cell anemia.

5. Rosado E, Paixao P, Schmitt W, Penha D, Carvalho FMPD, et al. (2014) Sickle cell anaemia- a review of the imaging findings. European Society of Radiology.

6. Platt OS, Brambilla DJ, Rosse WF, Milner PF, Castro O, et al. (1994) Mortality in sickle cell disease. Life expectancy and risk factors for early death. N Engl J Med 330: 1639-1644. [Crossref]

7. Berger E, Saunders N, Wang L, Friedman JN (2009) Sickle cell disease in children: differentiating osteomyelitis from vaso-occlusiove crises. Archives of Pediatrics and Adolescent Medicine Journal 163: 251-255.

8. Piehl FC, Davis RJ, Prugh SI (1993) Osteomyelitis in sickle cell disease. J Pediatr Orthop 13: 225-227. [Crossref]

9. Wong AL, Sakamoto KM, Johnson EE (2001) Differentiating osteomyelitis from bone infarction in sickle cell disease. Pediatr Emerg Care 17: 60-63. [Crossref]

10. Keeley K, Buchanan GR (1982) Acute infarction of long bones in children with sickle cell anemia. J Pediatr 101: 170-175. [Crossref]

11. Almeida A, Roberts I (2005) Bone involvement in sickle cell disease. Br J Haematol 129: 482-490. [Crossref]

12. Jain R, Swahney S, Rizvi SG (2008) Acute bone crises in sickle cell disease: the T1 fatsaturated sequence in differentiation of acute bone infarcts from acute osteomyelitis. Clinical Radiology 63: 59-70.

13. Umans H, Haramati N, Flusser G (2000) The diagnostic role of gadolinium enhanced MRI in distinguishing between acute medullary bone infarct and osteomyelitis. Magnetic Resonance Imaging 18: 255-262.

14. Bonnerot V, Sebag G, de Montalembert M, Wioland M, Glorion C, et al. (1994) Gadolinium-DOTA enhanced MRI of painful osseous crises in children with sickle cell anemia. Pediatr Radiol 24: 92-95. [Crossref]

15. Ebong WW (1986) Acute osteomyelitis in Nigerians with sickle cell disease. Ann Rheum Dis 45: 911-915. [Crossref]

16. Ebong WW (1987) Septic arthritis in patients with sickle-cell disease. Br J Rheumatol 26: 99-102. [Crossref]

17. Givner LB, Luddy RE, Schwartz AD (1981) Etiology of osteomyelitis in patients with major sickle haemoglobinopathies. Journal of Pediatrics 99: 411-413.

18. Bahebeck J, Atangana R, Techa A, Monny-Lobe M, Sosso M, et al. (2004) Relative rates and features of muscloskeletal complications in adult sicklers. Acta Orthopcedica Belgica 70: 107-111.

19. Almeida A, Roberts I (2005) Bone involvement in sickle cell disease. Br J Haematol 129: 482-490. [Crossref]

20. Resnick D (2002) Hemoglobinopathies and other anemias. In: D. Resnick, ed. Diagnosis of bone and joint disorders. Philadelphia: Saunders.

21. Burnett MW, Bass JW, Cook BA (1998) Etiology of osteomyelitis complicating sickle cell disease. Pediatrics 101: 296-297. [Crossref]

22. Kooy A, de Heide LJ, ten Tije AJ, Mulder AH, Tanghe HL, et al. (1996) Vertebral bone destruction in sickle cell disease: infection, infarction or both. Neth J Med 48: 227-231. [Crossref]

23. Anand AJ, Glatt AE (1994) Salmonella osteomyelitis and arthritis in sickle cell disease Semin Arthritis Rheum 24: 211-221. [Crossref]

24. Unkila-Kallio L, Kallio MJ, J Eskola, H Peltola (1994) Serum C-reactive protein, erythrocyte sedimentation rate, and white blood cell count in acute hematogenous osteomyelitis of children. Pediatrics 93: 59-62.

25. Fritz JM, McDonald JR (2008) Osteomyelitis: approach to diagnosis and treatment Phys Sportsmed 36: nihpa116823. [Crossref]

26. Lonergan GJ, Cline DB, Abbondanzo SL (2001) Sickle cell anemia. Radiographics 21: 971-994. [Crossref]

27. Sidhu PS, Rich PM (1999) Sonographic detection and characterization of musculoskeletal and subcutaneous tissue abnormalities in sickle cell disease. $\mathrm{Br} J$ Radiol 72: 9-17. [Crossref]

28. William RR, Hussein SS, Jeans WD, Wali YA, Lamki ZA (2000) A prospective study of soft-tissue ultrasonography in sickle cell disease patients with suspected osteomyelitis. Clinical Radiology 55: 307-310.

29. Rifai A, Nyman R (1997) Scintigraphy and ultrasonography in differentiating osteomyelitis from bone infarction in sickle cell disease. Acta Radiol 38: 139-143. [Crossref]

30. Sadat-Ali M, Al Umran K, Al Habdan I, Al Mulhim F (1998) Ultrasonography: can it differentiate between vasoocclusive crises and acute osteomyelitis in sickle cell disease? Journal of Pediatric Orthropedics 18: 552-554.

31. Riebel T, Kebelmann-Betzing C, Gotze R, Overberg U (2003) Transcranial Doppler ultrasonography in neurologically asymptomatic children and young adults with sickle cell disease. European Radiology 13: 563-570.

32. Crowley JJ, Sarnaik S (1999) Imaging of sickle cell disease. Pediatr Radiol 29: 646661. [Crossref]

33. Kim SK, Miller JH (2002) Natural history and distribution of bone and bone marrow infarction in sickle hemoglobinopathies. J Nucl Med 43: 896-900. [Crossref]

34. Amundsen TR, Siegel MJ, Siegel BA (1984) Osteomyelitis and infarction in sickle cell hemoglobinopathies: differentiation by combined technetium and gallium scintigraphy. Radiology 153: 807-812.

35. Buchanan GR (1996) Differentiation of bone infarct from infection in a child in sickle cell disease. Pediatr Infect Dis $J$ 15: 725. [Crossref]

36. Deely DM, Schweitzer ME (1997) MR imaging of bone marrow disorders. Radiol Clin North Am 35: 193-212. [Crossref]

37. Frush DP, Heyneman LE, Ware RE, Bissette GS (1999) MR features of soft-tissue abnormalities due to acute marrow infarction in five children with sickle cell disease. American Journal of Roentgenology 173: 989-993.

38. Bonnerot V, Sebag G, de Montalembert M, Wioland M, Glorion C, et al. (1994) Gadolinium-DOTA enhanced MRI of painful osseous crises in children with sickle cell anemia. Pediatr Radiol 24: 92-95. [Crossref]

Copyright: (2017 AlDallal SM. This is an open-access article distributed under the terms of the Creative Commons Attribution License, which permits unrestricted use, distribution, and reproduction in any medium, provided the original author and source are credited. 